\title{
FAKTOR RISIKO YANG MEMENGARUHI KEJADIAN DEMAM TIFOID DI WILAYAH KERJA PUSKESMAS BINAKAL KABUPATEN BONDOWOSO
}

\author{
Ria Rahmi Rahmawati \\ Departemen Kesehatan Lingkungan, Fakultas Kesehatan Masyarakat \\ Universitas Airlangga \\ Email: riarahmir@gmail.com
}

\begin{abstract}
Bondowoso Regency is an area that has the highest prevalence of typhoid fever in East Java. Typhoid fever is an acute infectious disease caused by Salmonella typhi bacteria. One area that contributes to typhoid fever in the Bondowoso Regency is in Binakal District. Recorded in 2018 typhoid fever falls into the top five diseases that often occur. This research was conducted in 2018 to determine the risk factors associated with the incidence of typhoid fever in the Binakal Community Health Center Bondowoso District. This study is an observational analytic study, with a case-control research design. The case population in the study was typhoid fever patients in 2018, while the control population was a group neighbour of cases who did not suffer from typhoid fever. The sample in this study were 36 people, where the ratio of the case group and control group respondents was 1:1. The independent variables studied included the quality of faeces disposal facilities and handwashing with soap after defecation with the dependent variable, the incidence of typhoidfever in the Binakal Health Center Working Area, Bodowoso District. The results showed that there were a relationship between age $(p=0,040)$ faeces disposal facilities and the incidence of typhoid fever with $p=0.001(\mathrm{OR}=$ 0.047), and there was a relationship between handwashing with soap after defecation with the incidence of typhoid fever with a value of $p=0.007(O R=0.143)$, there is a relationship between handwashing before meals with the incidence of typhoid fever with a value of $p=0.003(O R=0.110)$, and there was no relationship between gender with typhoid fever $(p=0,183)$.
\end{abstract}

Keywords: Typhoid Fever, Risk Factors, Salmonella typhi Bacteria, Handwashing

\begin{abstract}
ABSTRAK
Kabupaten Bondowoso merupakan daerah yang mempunyai prevalensi demam tifoid tertinggi di Jawa Timur. Demam tifoid merupakan suatu penyakit infeksi akut yang disebabkan oleh bakteri Salmonella typhi. Salah satu daerah yang menyumbang penyakit demam tifoid di wilayah Kabupaten Bondowoso adalah di Kecamatan Binakal. Tercatat pada tahun 2018 penyakit demam tifoid masuk ke dalam lima besar penyakit yang sering terjadi. Penelitian ini dilakuakn pada tahun 2018 untuk mengetahui faktor risiko yang berhubungan dengan kejadian demam tifoid di Wilayah Kerja Puskesmas Binakal Kabupaten Bondowoso. Penelitian ini merupakan penelitian observasional analitik, dengan rancang bangun penelitian case control. Populasi kasus dalam penelitian merupakan penderita demam tifoid pada tahun 2018, sedangkan populasi kontrol merupakan tetangga kelompok kasus yang tidak menderita demam tifoid. Sampel pada penelitian ini sebanyak 36 orang, dimana perbandingan responden kelompok kasus dan kelompok kontrol adalah 1:1. Variabel bebas yang
\end{abstract}


diteliti meliputi kualitas sarana pembuangan tinja dan cuci tangan dengan sabun setelah buang air besar dengan variabel terikat yakni kejadian demam tifoid di Wilayah Kerja Puskesmas Binakal, Kabupaten Bodowoso. Hasil penelitian menunjukkan terdapat hubungan antara umur $p=0,040$, sarana pembuangan tinja dengan kejadian demam tifoid dengan $p=0,001(\mathrm{OR}=0,047)$, dan terdapat hubungan antara mencuci tangan dengan sabun setelah buang air besar dengan kejadian demam tifoid dengan nilai $p=0,007$ ( $\mathrm{OR}=0,143$ ), ada hubungan antara mencuci tangan sebelum makan dengan kejadian demam tifoid dengan nilai $p=0,003(\mathrm{OR}=0,110)$, serta tidak ada hubungan antara jenis kelamin dengan kejadian demam tifoid $(\mathrm{p}=0,183)$

Kata kunci: Demam Tifoid, Faktor Risiko, Bakteri Salmonella typhi, Mencuci Tangan

\section{PENDAHULUAN}

Demam tifoid merupakan penyakit yang disebabkan oleh kuman Salmonella typhi, kuman tersebut menyerang sistem pencernaan dengan gejala yang tampak adalah demam selama satu minggu atau lebih dan disertai gangguan pada saluran pencernaan dengan atau tanpa gangguan kesadaran. Demam tifoid termasuk kedalam penyakit yang diinfeksi oleh bakteri. Penyakit demam tifoid biasanya ditularkan dari makanan serta minuman yang terkontaminasi bakteri Salmonella typhi ${ }^{1}$. Bakteri Salmonella typhi mempunyai sifat patogen yang dapat menginfeksi manusia maupun hewan. Salmonella typhi dapat bertahan hidup di alam bebas seperti di dalam air, tanah atau bahkan pada makanan. Iklim tropis adalah salah satu iklim yang sangat disenangi oleh bakteri tersebut, oleh karena itu penyakit demam tifoid menjadi bersifat endemik di Indonesia ${ }^{2}$.

Kejadian penyakit demam tifoid di negara maju mencapai 5.700 kasus setipa tahunnya, sedangkan di negara berkembang kejadian demam tifoid lebih tinggi yakni sebesar 21,5 juta jiwa per tahun ${ }^{3}$. Setiap tahunnya diperkirakan terjadi 21 juta kasus demam tifoid secara global dan 222.000 diantaranya menyebabkan kematian. Di negara berpenghasilan rendah dan menengah, demam tifoid menjadi penyebab utama terjadinya mortalitas dan morbiditas ${ }^{4}$. Penelitian yang dilakukan oleh Sur di daerah Kolkata, India menyatakan bahwa masyarakat dengan status ekonomi rendah berisiko tinggi terkena demam tifoid $^{5}$. Demam tifoid di Indonesia masih bersifat endemik. Penderita demam tifoid di Indonesia pada tahun 2008 mencapai angka 81,7 ribu per 100.000 jiwa $^{6}$. Pada tahun 2010 menurut profil kesehatan Indonesia penderita demam tifoid dan paratifoid sejumlah 41,081 kasus, baik kasus rawat inap mauapun rawat jalan dengan pasien meninggal dunia sebanyak 276 jiwa $^{7}$. Demam tifoid juga terjadi di kabupaten Bondowoso sebagai daerah tertinggi di Jawa Timur dengan prevalensi kejadian $3,48 \%{ }^{8}$.

Menurut penelitian yang dilakuakn oleh Dahlan, Ahmad., Munawar, Akhsin., Supriadi tahun 2014 dalam studi pendahuluan yang dilakukan di daerah desa Lambur keadaan 
lingkungan yang kurang memenuhi syarat kesehatan yang menjadi alasan tingginya angka kejadian demam tifoid di daerah tersebut ${ }^{9}$. Masyarakat setempat masih menggunakan air sungai yang juga digunakan untuk $\mathrm{BAB} / \mathrm{BAK}$ sebagai sarana cuci mandi dan juga kakus. Penelitian lain yang dilakukan oleh Artanti tahun 2012 terdapat hubungan yang signifikan antara sarana pembuangan tinja dengan kejadian demam tifoid $^{10}$. Penularan penyakit yang disebabkan oleh kuman Salmonella typhi ini sebagian besar ditularkan melalui makanan dan juga minuman. Adanya penularan tersebut maka yang berperan dari transmisi bakteri melalui higyene makanan dan higyene personal ${ }^{11}$. Higyene personal masyarakat berkaitan erat dengan kebiasaan mencuci tangan dengan sabun setelah buang air besar dan mencuci tangan dengan sabun sebelum makan. Penyakit demam tifoid juga merupakan penyakit yang multifaktoral dimana faktor penularannya dapat melalui berbagai hal seperti faktor umur, jenis kelamin, sanitasi lingkungan, pekerjaan, pendidikan, personal higyene, serta tempat tinggal penderita ${ }^{12}$.

Hasil uji statistik menunjukkan responden yang tidak memiliki sarana pembuangan tinja yang baik berisiko 5,333 kali terkena penyakit demam tifoid dari pada responden yang meimiliki sarana pembuangan tinja baik. Sarana pembuangan tinja yang tidak baik dapat menyebarkan kuman Salmonella typhi yang berada di dalam feses melalui perantara binatang atau vektor seperti tikus dan juga lalat. Menurut penelitian yang dilakukan oleh Ahmad Dahlan dan Akhsin Munawar tahun 2014, menyatakan bahwa ada hubungan antara sarana pembuangan tinja dengan kejadian demam tifoid di Wilayah Kerja Puskesmas Lambur dikarenakan masyarakat setempat mempunyai kebiasaan buang air besar sembarangan (BABS) ${ }^{9}$.

Menurut Profil Kesehatan Jawa Timur Tahun 2016 daerah yang memiliki peringkat empat terbawah tentang sanitasi layak dibawah $50 \%$ adalah Kabupaten Bondowoso. Sanitasi layak yang dimaksud salah satunya adalah tentang dari ODF (Open Defecation Free). Kabupaten Bondowoso merupakan salah satu wilayah di Jawa Timur yang belum memenuhi syarat sebagai Kabupaten yang telah ODF dikarenakan sebagian besar penduduknya masih mempraktikan buang air besar sembarangan (BABS). Total penduduk di Kabupaten Bondowoso mencapai 757 ribu orang dan 118.225 keluarga diantaranya melakukan buang air besar sembarang (BABS). Angka tersebut menempatkan Bondowoso sebagai daerah lima terbawah tentang sarana sanitasi layak yakni posisi 35 dari 38 Kabupaten di Jawa Timur ${ }^{13}$.

Menurut data Riskesdas tahun 2007, menyebutkan bahwa Kabupaten Bondowoso memiliki prevalensi kejadian demam tifoid tertinggi di Jawa Timur, yakni sebesar 3,48\% kasus $^{8}$. Salah satu wilayah di Kabupaten Bondowoso yang menyumbang angka kesakitan demam tifoid salah satunya adalah Kecamatan 
Binakal. Kecamatan Binakal berada di sebelah barat dari Ibu Kota Kabupaten Bondowoso, dan sebagian besar wilayahnya adalah dataran tinggi. Kejadian demam tifoid di Kecamatan Binakal pada awal tahun 2018 yakni dari bulan Januari-Mei masuk ke dalam 5 penyakit tertinggi mencapai angka 61 kasus.

\section{METODE PENELITIAN}

Awal proses penelitian dilakukan studi literatur dari berbagai literatur yang berkaitan dengan sanitasi lingkungan, higiene personal maupun yang berkaitan dengan demam tifoid. pendekatan yang dilakukan menggunakan observasional karena mendapatkan data primer dari hasil tanya jawab menggunakan kuesioner. Ditinjau dari waktu pengambilan data, penelitian ini termasuk penelitian case control, dimana penelitian ini menggunakan pendekatan retrospektif (melihat kebelakang) yang bertujuan untuk mengetahui penyebab penyakit dengan menelusuri faktor risiko pada kejadian.

Ananlisi data menggunakan uji statistik chi square, hal ini dilakukan untuk menganalisis hubungan kualitas sarana pembuangan tinja dan cuci tangan dengan sabun setelah buang air besar dengan kejadian demam tifoid di Wilayah Kerja Puskesmas Binakal Kabupaten Bondowoso. Penelitian ini dilakukan dengan menganalisa hubungan yang memiliki nilai signifikan $(\mathrm{p}<0,05)$ dari faktor risiko yang terdapat pada variabel kualitas sarana pembuangan tinja dan cuci tangan dengan sabun setelah buang air besar dengan kejadian demam tifoid di Wilayah Kerja Puskesmas Binakal Kabupaten Bondowoso.

Populasi yang digunakan dalam penelitian ini adalah seluruh populasi kasus dan populasi kontrol. Populasi kasus yaitu seluruh pederita demam tifoid di wilayah kerja puskesmas Binakal kabupaten Bondowoso pada tahun 2018. Sedangkan populasi kontrol yaitu semua orang yang berada di wilayah kerja puskesmas Binakal kabupaten Bondowoso yang memenuhi kriteria inklusi. Dalam pengambilan data pada penelitian ini dari populasi yang didapat diambil sampek menggunakan metode rumus Lameshow. Berdasarkan perhitungan rumus didapatkan besar sampel penelitian sebanyak 18 orang. Untuk besar sampel kasus dan kontrol dengan perbandingan 1:1. Sehingga besar sampel penelitian yang akan digunakan yaitu kelompok kasus demam tifoid di wilayah kerja puskesmas Binakal kabupaten Bondowoso berjumlah 18 orang dan 18 kelompok kontrol dengan yang berarti keseluruhan jumlah 36 responden.

\section{HASIL DAN PEMBAHASAN \\ Hasil}

Analisis univariat pada penelitian ini dilakukan dengan menggunakan distribusi dan presentasi dari setiap hasil data yang diperolah. Variabel bebas dalam penelitian ini adalah sarana tempat pembuangan tinja, umur, jenis kelamin, mencuci tangan dengan sabun setelah buang air besar, dan mencuci tangan dengan 
sabun sebelum makan. Sedangkan analisi bivariat dilakukan dengan menggunakan uji Chi-Square $\left(\mathrm{x}^{2}\right)$ dengan menggunakan $\alpha=0,05$ dan Confidence Interval (CI) sebesar 95\%, estimasi besar sampel dihitung dengan menggunakan odds ratio (OR). Uji chi square yang digunakan bertujuan untuk mengetahui vhubungan variabel kategorik dengan kategorik. Pengambilan keputusan berdasarkan nilai $\mathrm{p}$ value. Apabila $\mathrm{p}$ value $\geq \alpha(0,05)$ maka Ho diterima dan apabila $\mathrm{p}$ value $<\alpha(0,05)$ maka Ho ditolak. Berikut adalah hasil dari penelitian yang dilakukan di Wilayah Kerja Puskesmas Binakal Kabupaten Bondowoso tentang hubungan kualitas sarana pembuangan tinja dan cuci tangan dengan sabun setelah buang air besar dengan kejadian demam tifoid.

Lokasi penelitian dalam penelitian ini adalah di Wilayah Kerja Puskesmas Binakal, Kecamatan Binakal, Kabupaten Bondowoso. Kecamatan Binakal mempunyai luas wilayah $27.370 \mathrm{Km}^{2}$. Jumlah penduduk sampai dengan tahun 2016 adalah sebanyak 15.391 jiwa. Kecamatan Binakal berada di sebelah barat dari ibu kota Kabupaten Bondowoso, yakni berjarak sekitar $7 \mathrm{~km}$ dari pusat kota. Kecamatan Binakal terdiri dari 8 desa yakni desa Binakal, Gading Sari, Sumber Waru, Baratan, Kembangan, Bendelan, Sumber Tengah, dan desa Jeuk Soksok, dengan pusat pemerintahan dan kesehatan berada di desa Binakal. letak geografis Kecamatan Binakal antara 70\% dataran tinggi dan 30\% dataran rendah dengan ketinggian rata- rata $\pm 283 \mathrm{~m}$ dpal dan suhu berkisar antara 22 23 derajat Celcius serta luas wilayah Kecamatan Binakal adalah 27,370 $\mathrm{km}^{2}$ berdasarkan data BPS tahun 2016.

Distribusi umur responden dalam penelitian ini adalah umur produktif dari rentan umur 15-64 tahun. Kemudian kelompok umur tersebut dibedakan menjadi dua, yakni $\leq 30$ tahun yang merupakan umur yang berisiko terkena penyakit dan umur $>30$ tahun, merupakan umur yang tidak berisiko terkena penyakit.

Tabel 1. Hubungan Umur dengan Kejadian Demam Tifoid di Wilayah Kerja Puskesmas Binakal Kabupaten Bondowoso Tahun 2018

\begin{tabular}{lrlrlll}
\hline \multirow{2}{*}{ Umur } & \multicolumn{6}{c}{ Kejadian Demam Tifoid } \\
\cline { 2 - 7 } & \multicolumn{1}{c}{ Ya } & \multicolumn{3}{c}{ Tidak } & \multicolumn{3}{c}{ mlah } \\
\cline { 2 - 7 } & $\mathrm{n}$ & $\%$ & $\mathrm{n}$ & $\%$ & $\mathrm{n}$ & $\%$ \\
\hline 30 Tahun & 14 & 38,9 & 8 & 22,2 & 22 & 61,1 \\
\hline 30 Tahun & 4 & 11,1 & 10 & 27,8 & 14 & 38,9 \\
\hline Jumlah & 18 & 50,0 & 18 & 50,0 & 36 & 100,0 \\
\hline$p$-Value $=0,040, \mathrm{OR}=4,375$ \\
$\mathrm{CI}=95 \%$ & $(1,027<\mathrm{OR}>18,629)$
\end{tabular}

Berdasarkan Tabel 1 diketahui bahwa umur $\leq 30$ tahun terdapat 14 dari 22 responden baik pada kelompok kasus maupun kelompok kontrol positif demam tifoid. Sementara, hanya sebanyak 4 responden atau $11,1 \%$ positif demam tifoid dari kelompok umur $>30$ tahun.

Jenis kelamin responden diklasifikasikan menjadi dua, yaitu laki-laki dan perempuan. Distribusi jenis kelamin di Wilayah Kerja Puskesmas Binakal Kabupaten dalam penelitian ini dapat dilihat pada Tabel 2. 
Tabel 2. Hubungan Jenis Kelamin dengan Kejadian Demam Tifoid di Wilayah Kerja Puskesmas Binakal Kabupaten Bondowoso Tahin 2018

\begin{tabular}{lrrrrrr}
\hline \multirow{2}{*}{$\begin{array}{c}\text { Jenis } \\
\text { Kelamin }\end{array}$} & \multicolumn{4}{c}{ Kejadian Demam Tifoid } \\
\cline { 2 - 7 } & \multicolumn{2}{c}{ Ya } & \multicolumn{2}{c}{ Tidak } & \multicolumn{2}{c}{ Jumlah } \\
\cline { 2 - 7 } & $\mathrm{n}$ & $\%$ & $\mathrm{n}$ & $\%$ & $\mathrm{n}$ & $\%$ \\
\hline Perempuan & 12 & 33,3 & 8 & 22,2 & 20 & 50,0 \\
\hline Laki-laki & 6 & 16,7 & 10 & 27,8 & 16 & 50,0 \\
\hline Jumlah & 18 & 50,0 & 18 & 50,0 & 36 & 100,0 \\
\hline
\end{tabular}
p value $=0,180, \mathrm{OR}=2,500$

$\mathrm{CI}=95 \%(0,648<\mathrm{OR}>9,651)$

Hasil penelitian menunjukkan bahwa tidak ada hubungan antara jenis kelamin dengan kejadin demam tifoid di Wilayah Kerja Puskesmas Binakal Kabupaten Bondowoso. Sebagian besar responden dengan positif demam tifoid adalah perempuan $(33,3 \%)$. Sedangkan responden laki-laki dari 16 responden hanya 6 responden positif demam tifoid.

Cuci tangan dengan sabun juga merupakan faktor risiko yang sering menyebabkan demam tifoid. Hubungan cuci tangan dengan sabun setelah buang air besar dapat dilihat di Tabel 3.

Tabel 3. Hubungan Sarana Pembuangan Tinja dengan kejadian demam tifoid di Wilayah Kerja Puskesmas Binakal Kabupaten Bondowoso Tahin 2018

\begin{tabular}{|c|c|c|c|c|c|c|c|}
\hline \multirow{3}{*}{$\begin{array}{c}\text { Sarana } \\
\text { Pembuan } \\
\text { gan Tinja }\end{array}$} & \multicolumn{6}{|c|}{ Kejadian Demam Tifoid } & \multirow{3}{*}{$\begin{array}{c}p \\
\text { val } \\
\text { ue }\end{array}$} \\
\hline & \multicolumn{2}{|c|}{ Ya } & \multicolumn{2}{|c|}{ Tidak } & \multicolumn{2}{|c|}{ Jumlah } & \\
\hline & $\mathrm{n}$ & $\%$ & $\mathrm{n}$ & $\%$ & $\mathrm{n}$ & $\%$ & \\
\hline $\begin{array}{l}\text { Memenuhi } \\
\text { Syarat }\end{array}$ & 1 & 2,8 & 10 & 27,8 & 11 & 30,6 & \\
\hline $\begin{array}{l}\text { Tidak } \\
\text { Memenuhi } \\
\text { Syarat }\end{array}$ & $\begin{array}{l}1 \\
7\end{array}$ & 47,2 & 8 & 22,2 & 25 & 69,4 & $\begin{array}{l}0,0 \\
01\end{array}$ \\
\hline Jumlah & $\begin{array}{l}1 \\
8\end{array}$ & 50,0 & 18 & 50,0 & 36 & 100,0 & \\
\hline
\end{tabular}

Hasil penelitian menunjukan bahwa responden yang terbiasa tidak mencuci tangan dengan sabun setelah buang air besar cenderung menderita penyakit demam tifoid. 14 dari 19 responden positif demam tifoid sementara hanya 4 dari 17 responden positif demam tifoid padahal telah mencuci tangan dengan sabun setelah buang air besar. Hasil uji statistik chi-square menunjukkan nilai $p=0,007(p<\alpha)$ artinya ada hubungan signifikan antara cuci tangan dengan sabun setelah buang air besar dengan kejadian demam tifoid.

Berdasarkan hasil pengujian hubungan antara kebiasaan mencuci tangan dengan sabun sebelum makan dengan kejadian demam tifoid didapatkan hasilseperti pada Tabel di bawah ini:

Tabel 4. Hubungan Cuci Tangan dengan Sabun Sebelum Makan dengan kejadian demam tifoid di Wilayah Kerja Puskesmas Binakal Kabupaten Bondowoso Tahin 2018

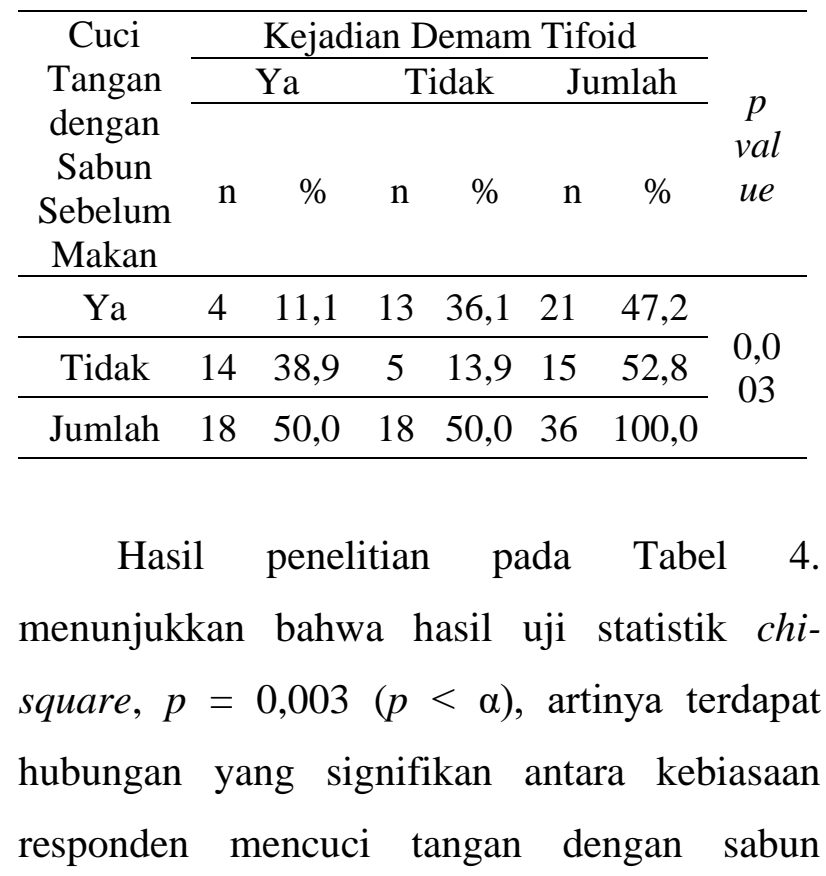


sebelum makan dengan kejadian demam tifoid. 14 dari 15 responden yang terbiasa tidak mencuci tangan dengan sabun sebelum makan pernah mengalami penyakit demam tifoid. Sementara itu, hanya 4 dari 21 responden yang terbiasa mencuci tangan dengan sabun yang pernah mengalami penyakit demam tifoid.

Berdasarkan hasi pengamatan dilapangan didapatkan data jamban yang dipakai responden adalah sebagai berikut:

Tabel 5. Hubungan Cuci Tangan dengan Sabun dengan kejadian demam tifoid di Wilayah Kerja Puskesmas Binakal Kabupaten Bondowoso Tahin 2018.

\begin{tabular}{|c|c|c|c|c|c|c|c|}
\hline \multirow{3}{*}{$\begin{array}{c}\text { Cuci } \\
\text { Tangan } \\
\text { dengan } \\
\text { Sabun } \\
\text { Setelah } \\
\text { BAB } \\
\end{array}$} & \multicolumn{6}{|c|}{ Kejadian Demam Tifoid } & \multirow{3}{*}{$\begin{array}{c}p \\
\text { val } \\
\text { ue }\end{array}$} \\
\hline & \multicolumn{2}{|c|}{$\mathrm{Ya}$} & \multicolumn{2}{|c|}{ Tidak } & \multicolumn{2}{|c|}{ Jumlah } & \\
\hline & $\mathrm{n}$ & $\%$ & $\mathrm{n}$ & $\%$ & $\mathrm{n}$ & $\%$ & \\
\hline Ya & 4 & 11,1 & 12 & 66,7 & 17 & 44,4 & 0,0 \\
\hline Tidak & 14 & 38,9 & 6 & 16,7 & 19 & $\overline{55,6}$ & 07 \\
\hline Jumla & 18 & 50,0 & 18 & 50,0 & 36 & 100,0 & \\
\hline
\end{tabular}

Hasil dari uji statistik chi-square menunjukkan bahwa $p=0,001(p<\alpha)$, artinya ada hubungan antara sarana pembuangan tinja dengan kejadian demam tifoid di wilayah kerja puskesmas Binakal kabupaten Bondowoso. Hasil penelitian menunjukkan bahwa 14 dari 21 responden yang menggunakan sarana pembuangan tinja yang tidak memenuhi syarat memiliki riwayat positif demam tifoid. Sedangakan hanya 4 dari 15 responden yang memiliki sarana pembuangan tinja yang memenuhi syarat tercatat positif demam tifoid.

\section{Pembahasan}

Berdasarkan hasil penelitian pada variabel umur diketahui bahwa terdapat hubungan anatara umur dengan kejadian demam tifoid di Wilayah Kerja Puskesmas Binakal Kabupaten Bondowoso. Hasil chi square diperoleh $p$ $(0,040)>\alpha(0,05)$, sehingga Ho diterima yang berarti ada hubungan antar keduanya. Dari hasil penelitian di lapangan didapatkan sebagian besar responden baik pada kelompok kasus maupun kelompok kontrol mempunyai umur yang berisiko ( $\leq 30$ tahun $)$ sebanyak 22 responden, 14 responden atau 38,9\% diantaranya positif demam tifoid. Diketahui juga bahwa hasil OR sebesar 4,357 yang artinya responden yang mempunyai umur $\leq 30$ tahun mempunyai risiko 4,357 kali terkena demam tifoid.

Demam tifoid biasanya menyerang pada usia produkti pada rentan umur 15-64 tahun. Hal tersebut sejalan dengan penelitian Hamidatul et al.yang menyatakan bahwa kasus demam tifoid paling banyak terjadi pada kelompok usia produktif, Pada penelitian tersebut responden yang sebagian besar menderita penyakit demam tifoid adalah pada kelompok umur 15-30 tahun yakni sebesar 93\% dari keseluruhan kelompok kasus $^{14}$. Penelitian lain yang dilakukan oleh Paputungan et al. yang juga menyebutkan bahwa penderita demam tifoid sebagian besar berumur 15-30 tahun yaitu sebanyak 49,33\% dari total responden yang diteliti ${ }^{15}$. Sementara itu, penelitian yang dilakukan oleh Wulansari 
menyebutkan bahwa penderita demam tifoid sebagian besar juga diderita oleh responden berusia produktif yaitu rentan umur 20-25 tahun yaitu sebanyak $51,3 \%{ }^{16}$.

Berdasarkan uji statistik chi square yang dilakukan didapatkan hasil $\mathrm{p}(0,180)>\alpha(0,05)$ yang artinya tidak ada hubungan antara jenis kelamin dengan kejadian demam tifoid di wilayah kerja puskesmas Binakal kabupaten Bondowoso. Sehingga dalam penelitian ini dapat dikatakan bahwa variabel jenis kelamin bukan sebagai faktor risiko terjadinya demam tifoid. Variabel jenis kelamin sebagian besar resonden pada kelompok kasus dan kelompok kontrol adalah perempuan.

Kelompok kasus sebagian besar berjenis kelamin perempuan dibandingkan dengan jenis kelamin laki-laki. Meskipun demikian penyakit demam tifoid adalah penyakit yang dapat menyerang segala kalangan baik jenis kelamin perempuan maupun jenis kelamin laki-laki. Menurut penelitian yang dilakukan oleh Wulansari, sebagian besar penderita demam tifoid adalah berjenis kelamin perempuan yakni $66,7 \%$. Sebagian besar penderita demam tifoid dalam penelitian menunjukkan jenis kelamin perempuan lebih berisiko baik pada kelompok kasus maupun kelompok kontrol ${ }^{16}$. Hasil penelitian menunjukkan bahwa tidak ada hubungan antara jenis kelamin dengan kejadin demam tifoid di Wilayah Kerja Puskesmas Binakal Kabupaten Bondowoso. Sebagian besar responden dengan positif demam tifoid adalah perempuan yakni, dari 20 responden sejumlah 12 responden $(33,3 \%)$ positif demam tifoid, sedangkan responden laki-laki dari 16 responden hanya 6 responden positif demam tifoid.

Pada variabel mencuci tangan dengan sabun setelah buang air besar didapatkan hasil $\mathrm{p}$ $=0,007$ dan hasil OR 0,143 dengan menggunakan $\mathrm{CI}=95 \%$. Sebanyak 14 dari 19 responden yang terbiasa tidak mencuci tangan setelah buang air besar positif demam tifoid, sedangkan hanya sebanyak 4 dari 17 respon yang mencuci tangan dengan sabun setelah buang air besar yang tercatat positif demam tifoid. Resonden yang terbiasa tidak mencuci tangan dengan sabun setelah buang air besar mempunyai risiko 0,143 kali terkena penyakit demam tifoid dari pada responden yang sering mencuci tangan dengan sabun setelah buang air besar artinya, ada hubungan yang signifikan antara mencuci tangan dengan sabun setelah buang air besar dengan kejadian demam tifoid di Wilayah Kerja Puskesmas Binakal Kabupaten Bondowoso.

Kebiasaan masyarakat yang sering baung air besar ke sungai merupakan faktor yang sangat berpengaruh terhadap kebiasaan budaya mencuci tangan setelah buang air besar. Masyarakat cenderung pergi ke sungai untuk buang air besar dengan tangan kosong artinya tidak membawa peralatan mandi seperti halnya sabun karena hal tersebut dianggap tidak efektif dan merepotkan. Daerah kecamatan Binakal 
merupaka kecamatan yang belum semua desa yang ada sudah tercatat sebagai desa ODF. Hal tersebut juga berkaitan dengan banyaknya aliran sungai yang mengalir sepanjang wilayah desa. air sungai tersebut berasal dari air pegunungan yang mengaliri hampir semua wilayah Kecamatan Binakal. Keadaan dimana sebagian besar masyarakat juga belum mempunyai fasilitas jamban pribadi di rumah menjadikan sungai sebagai alternatif untuk buang air besar.

Berdasarkan penelitian yang dilakukan, responden yang terbiasa mencuci tangan dengan sabun setelah buang air besar adalah responden yang mempunyai fasilitas jamban pribadi di rumah. Sabun atau antiseptik yang digunakan untuk mencuci tangan telah tersedia di kamar mandi atau sarana pembuangan tinja masingmasing rumah, hal tersebut yang mempermudah responden mencuci tangan dengan sabun setelah buang air besar dibandingkan dengan responden yang terbiasa buang air besar di sungai.

Penelitian yang dilakukan oleh Ulfa dan Handayani menyatakan bahwa terdapat hubungan antara mencuci tangan setelah buang air besar dengan sabun dengan kejadian demam tifoid di Wilayah Kerja Puskesmas Pagiyanten Kabupaten Tegal. Hasil uji statistik menggunakan chi square didapatkan $\mathrm{p}=0,04$ dengan $\mathrm{OR}=2,99$. Hasil OR menunjukkan bahwa responden yang tidak mencuci tangan dengan sabun setelah buang air besar mempunyai risiko 2,99 kali terkena penyakit demam tifoid dibandingkan dengan responden yang terbiasa mencuci tangan dengan sabun setelah buang air besar ${ }^{17}$. Bakteri atau virus patogen yang berada di tangan dapat berpindah ke dalam tubuh melalui makanan dan juga minuman yang terkontaminasi ${ }^{1}$. Oleh karena itu, tangan yang bersih dan bebas dari kuman dan virus harus dijadikan prioritas dengan cara membiasakan mencuci tangan selalu dengan sabun atau antiseptik lain. Meskipun pada praktiknya hal seperti mencuci tangan dengan sabun atau antiseptik lain, menggosok jari tangan dan kuku, serta menggunakan air mengalir sering disepelekan namun justru mempu menghanyutkan dan meminimalisir partikel kotoran yang banyak mengandung mikroorganisme yang menempel pada telapak $\operatorname{tangan}^{18}$.

Penelitian ini juga sejalan dengan yang dilakukan oleh Paputungan yang dilakukan di Wilayah Kerja Puskesmas Upai Kota Kotamobagu yang menyatakan bahwa ada hubungan yang signifikan antara kebiasaan mencuci tangan dengan sabun setelah buang air besar dengan kejadian demam tifoid, dengan nilai $\mathrm{p}(0,041)<\alpha(0,05){ }^{15}$. Penelitian lain yang dilakukan oleh Magfiroh disebutkan bahwa terdapat hubungan yang signifikan antara praktik cuci tangan setelah buang air besar dengan kejadian demam tifoid di Kelurahan Mlatibaru Kecamatan semaran Timur ${ }^{18}$. Hasil uji statistik pada variabel cuci tangan menggnakan uji chi square yakni p value 0,032 dan perhitungan risk estimate didapatkan OR 
3,263, hal tersebut menunjukkan bahwa responden yang terbiasa melakukan praktik cuci tangan setelah buang air besar yang kurang baik memiliki risiko terkena penyakit demam tifoid 3,263 kali dibandingkan dengan responden yang melakukan kebiasaan praktik cuci tang setelah buang air besar dengan baik.

Penelitian yang dilakukan oleh Hilda dan Fariani disebutkan bahwa sebanyak $75 \%$ anak yang terbiasa mencuci tangan sesudah buang air besar dengan kurang baik terdiagnosis menderita demam tifoid. Hasil OR juga menunjukkan bahwa anak yang terbiasa mencuci tangan sesudah buang air besar dengan kurang baik berisiko 3,67 kali terkena penyakit demam tifoid dibandingkan dengan anak yang terbiasa mencuci tangan sesudah buang air besar dengan baik $^{19}$. Menurut Zulkoni, disebutkan bahwa penularan demam tifoid dapat menular melalui berbagai cara yang dikenal dengan $5 \mathrm{~F}$ yaitu (food, finger, fomitus, fly, feses), feses serta muntahan dari penderita demam tifoid dapat menularkan bakteri Salmonella typhi kepada orang lain melalui air atau makan yang terkontminasi ${ }^{20}$. Penelitian yang dilakukan oleh Maghfiroh, juga menyatakan bahwa terdapat hubungan yang signifikan antara cuci tangan setelah buang air besar dengan kejadian demam tifoid di Kelurahan Mlatibaru Kecamatan Semarang Timur dengan nilai $p$ value 0,032. Kuman yang ditularkan melalui makanan atau minuman dapat diperantarai melalui lalat atau vektor lain dimana lalat ata vektor hinggap dimakanan yang dita makan, atau sekret terbawa bersama air dan menular kepada manusia yang lain ${ }^{18}$. Apabila orang tersebut kurang memperhatikan kebersihan dirinya seperti mencuci tangan setelah buang air besar atau sebelum makan maka bakteri Salmonella typhi dapat masuk ke dalam tubuh orang tersebut yang sehat melalui mulut dan selanjutnya orang sehat tersebut akan menjadi sakit.

Berdasarkan hasil uji bivariat menggunakan uji statistik chi square didapatkan kesimpulan bahwa terdapat hubungan antara sarana pembuangan tinja dengan kejadian demam tifoid. Sebesar $47,2 \%$ responden kelompok kasus memiliki sarana pembuangan tinja tidak memebuhi syarat, sedangkan pada kelompok kontrol sebagian besar responden yaitu $27,8 \%$ memiliki sarana pembuangan tinja memenuhi syarat dan tidak terjangkit demam tifoid. Sejalan dengan penelitian yang dilakukan oleh Nurvina, disebutkan bahwa sarana pembuangan tinja memiliki hubungan yang signifikan dengan kejadian demam tifoid $^{10}$. Menurut penelitian yang dilakukan oleh Dahlan dan Munawar di Wilayah Kerja Puskesmas Lambur, masih banyak responden yang buang air besar sembarang tempat ${ }^{9}$. Hal tersebut dilakukan karena masyarakat belum terbiasa menggunakan jamban, serta hasil dari promosi kesehatan yang dilakukan di daerah tersebut mengahsilkan informasi bahwa belum ada metode ataupun cara yang diinginkan responden dalam menggunakan jamban. Menurut 
penelitian yang dilakukan oleh Nurvina, sarana pembuangan tinja berhubungan dengan kejadian demam tifoid di Wilayah Kerja Puskesmas Kedungmundu Kota Semarang. Responden yang memiliki sarana pembuangan tinja yang tidak memenuhi syarat mempunyai risiko 5,333 kali lebih besar menderita demam tifoid daripada responden yang memiliki sarana pembuangan tinja yang memenuhi syarat ${ }^{10}$. Hasil survei di lapangan menunjukkan responden tidak memiliki sarana pembuangan tinja yang memenuhi syarat, beberapa responden mempunyai jarak antara sumber air minum dengan lubang penampungan kurang dari 11 meter dan masih terdapat sarana pembuangan tinja yang tidak dilengkapi dengan dinding dan atap pelindung.

Kecamatan Binakal merupakan salah satu kecamatan yang belum ODF di Kabupaten Bondowoso dikarenakan dari 8 desa yang ada di Kecamatan Binakal hanya dua desa yang mendapatkan peringkat hijau sementara dua desa mendapat peringkat kuning, dan empat desa lainnya mendapat peringkat merah untuk kepemilikan jamban sehat. Hal tersebut yang melatarbelakangi sebagaian besar masyarakat masih terbiasa buang air besar di sungai, dan tidak jarang juga masyarakat yang memiliki jamban, pada siang hari buang air besar di sungai tetapi ketika malam hari buang air besar di jamban pribadi masing-masing dengan alasan, buang air besar di sungai lebih nyaman untuk masyarakat.
Hasil uji bivariat pada variabel cuci tangan dengan sabun sebelum makan dengan kejadian demam tifoid didapatkan hasil bahwa terdapat hubungan antara keduanya. 14 dari 19 responden yang terbiasa tidak melakukan cuci tangan dengan sabun sebelum makan memiliki riwayat sakit demam tifoid, artinya $38,9 \%$ dari seluruh responden pernah mengalami demam tifoid dikarenakan tidak mencuci tangan dengan sabun sebelum makan. Cuci tangan sebelum makanan dengan sabun sebelum makan belum menjadi budaya yang sering dilakukan di daerah kecamatan Binakal, responden menganggap cuci tangan saja sudah cukup membuat tangan bersih tanpa menggunakan sabun atau antiseptik lainnya. Cara mencuci tangan yang dilakukan juga merupakan gerakan seadanya, yakni hanya dengan membasahi tangan dengan air. WHO menganjurkan enam langkah cuci tangan dengan sabun atau cairan antiseptik lain yang dapat meminimaisir atau bahkan membunuh kuman yang berada pada telapak tangan. Menurut Diana, selain didapatkan dari menelan makanan dan minuman penularan demam tifoid juga dapat ditularkan dari kontak langsung jari tangan yang terkontminasi tinja, urin, secret saluran nafas atau dengan pus penderita yang terinfeksi ${ }^{21}$. Kebersihan diri merupakan salah satu faktor penularan dari penyakit saluran pencernaan, penularan penyakit dapat melalui tangan yang tercemar oleh mikroorganisme patogen yang merupakan penyebab penyakit. Mencuci tangan setelah buang air besar atau 
mencuci tangan setelah makan dengan sabun atau antiseptik dapat melindungi seseorang dari infeksi penyakit. Selain kebersihan tangan, kebersihan kuku seseorang mempengaruhi terjadinya penyakit demam tifoid. Mencuci tangan dengan benar harus menggunakan sabun atau antiseptik serta air mengalir untuk menggosok sela-sela jari dan kuku dapat mencegah bakteri yang berada di kuku dan jari tangan masuk ke dalam tubuh ikut bersama makan atau minuman. Penelitian yang dilakukan oleh Rakhman, et al. menyatakan bahwa terdapat hubungan antara mencuci tagan sebelum makan pada orang dewasa usia $\geq 16$ tahun dengan kejadian demam tifoid di Bulungan, Kalimantan Timur ${ }^{22}$.

Menurut penelitian yang dilakukan oleh Nurvita, disebutkan bahwa ada hubungan yang bermakna antara mencuci tangan dengan sabun sebelum makan dengan kejadian demam tifoid ${ }^{10}$. Berdasarkan penelitian yang dilakukan didapatkan kesimpulan bahwa budaya mencuci tangan di wilayah kerja puskesmas Lambur belum terlaksana dengan baik dikarenakan sarana serta prasarana untuk mencuci tangan belum memenuhi syarat. Responden terbiasa mencuci tangan dengan air kobokan yang tidak mengalir sebelum makan tanpa menggunakan sabun.

Berdasarkan penelitian yang dilakukan oleh Fibriana, et al., disebutkan bahwa ada hubungan yang signifikan antara cuci tangan dengan sabun sebelum makan dengan kejadian demam tifoid.
Jumlah responden kasus yang tidak melakukan praktik cuci tangan dengan baik menggunakan sabun sebelum makan sebesar $71,4 \%$. Responden yang tidak mencuci tangan dengan sabun sebelum makan dengan baik mempunyai risiko 3,03 kali lebih besar dari responden yang mempunyai kebiasaan cuci tangan dengan sabun dengan baik sebelum makan ${ }^{23}$. Berdasarkan penelitian yang dilakukan tersebut menyatakan bahwa penularan penyakit saluran pencernaan salah satu faktor penyebabnya adalah melalui tangan yang tercemar oleh mikroorganisme patogen penyebab penyakit demam tifoid yakni Salmonella typhi.

\section{SIMPULAN DAN SARAN}

\section{Simpulan}

Dari hasil penelitian dapat disimpulkan bahwa sebagian besar kelompok kasus dan kelompok kontrol berada kelompok umur $\leq 30$ tahun. Sebagian besar kelompok kasus dan kelompok kontrol berjenis kelamin perempuan. Kebiasaan mencuci tangan dengan sabun setelah buang air besar pada kelompok kasus cenderung tidak memenuhi syarat dari pada kelompok kontrol. Berdasarkan kebiasaan mencuci tangan dengan sabun sebelum makan juga pada kelompok kasus cenderung tidak memenuhi syarat. Sanitasi lingkungan pada responden didapatkan hasil yaitu sebagian besar kelompok kasus tidak memiliki sarana pembuangan tinja yang memenuhi syarat yakni sebanyak 47,2\% dari akumulasi seluruh responden. 
Berdasarkan hasil analisa uji chi square didapatkan bahwa karakteristik individu yang meliputi umur, mencuci tangan dengan sabun setelah buang air besar, mencuci tangan dengan sabun sebelum makan berhubungan dengan kejadian demam tifoid di Wilayah Kerja Puskesmas Binakal Kabupaten Bondowoso. Disamping itu, kualitas sarana pembuangan tinja berhubungan dengan kejadian demam tifoid di Wilayah Kerja Puskesmas Binakal Kabupaten Bondowoso.

\section{Saran}

Bagi masyarakat terkait karakteristik individu untuk dapat membiasakan serta membudayakan gerakan cuci tangan dengan sabun baik setelah buang air besar dan sebelum makan menggunakan air yang mengalir dan sedikitnya dengan enam gerakan cuci tangan untuk membunuh kuman yang ada di tangan. Terkait dengan sanitasi lingkungan, sebaiknya mulai membiasakan diri untuk buang air besar di jamban pribadi atau umum, meminimalisir buang air besar sembarangan atau di sungai. Bagi dinas kesehatan perlu digalakkan kembali gerakan cuci tangan dengan sabun setelah buang air besar atau sebelum makan serta, peningkatan kampung odf di Wilayah Kerja Puskesmas Binakal Kabupaten Bondowoso. Bagi pemerintah setempat untuk dapat bekerja sama dengan instansi terkait untuk mmemnuhi sarana sanitasi yang baik bagi masyarakat menciptakan jamban yang layak bagi masyarakat.

\section{REFERENSI}

1. Rampengan, T. Penyakit Infeksi Tropik Pada Anak. Jakarta: EGC. 2007.

2. Monica, W.S., Mahatmi, H. \& Besung, K., Pola Resistensi Salmonella typhiyang Diisolasi dari Ikan Serigala (Hoplias malabaricus) terhadap Antibiotik.Jurnal Ilmu Kesehatan Hewan, 2013: 1(2), pp.6469.

3. Batubuaya, D., Ratag, B.T., Wariki, W. Hubungan Higiene Perorangan dan Aspek Sosial Ekonomi dengan Kejadian Demam Tifoid di Rumah Sakit Tk. III R.W. Mongisidi Manado. Jurnal Media Kesehatan. 2017: 9(3): 1-8.

4. WHO. 2016. Background Document:The Diagnosis, Treatment And Prevention Of Typhoid Fever. Geneva: World Health Organization.

5. Rakhman, A., Humardewayanti, R., Pramono, D. Faktor-faktor Risiko yang Berpengaruh Terhadap Kejadian Demam Tifoid Pada Orang Dewasa. Jurnal Berita Kedokteran Masyarakat, 2009: 25(4): pp:167-175

6. Kemenkes RI. Profil Kesehatan Indonesia. Jakarta: Badan Penelitian dan Pengembangan Kesehatan Kementerian Kesehatan Republik Indonesia. 2013.

7. Kemenkes RI. Profil Kesehatan Indonesia. Jakarta: Badan Penelitian dan Pengembangan Kesehatan Kementerian Kesehatan Republik Indonesia. 2010.

8. Kemenkes RI. Riset Kesehatan Dasar Tahun 2007. Jakarta: Badan Penelitian dan Pengembangan Kesehatan Kementerian Kesehatan Republik Indonesia. 2008.

9. Dahlan, A., Munawar, A., Supriadi. Hubungan Sanitasi Lingkungan dan Faktor Budaya dengan Kejadian Tifus di Wilayah Kerja Puskesmas Lambur Kabupaten Tanjung Jabung Timur Tahun 2013. Jurnal Ilmiah-Universitas Batanghari Jambi, 2014:14(1) 
10. Nurvina. Hubungan Antara Sanitasi Lingkungan, Higiene Perorangan, dan Karakteristik Individu dengan Kejadian Demam Tifoid di Wilayah Kerja Puskesmas Kedungmundu Kota Semarang Tahun 2012.Skripsi.Universitas Negeri Semarang. Tersedia di: < http://lib.unnes.ac.id/18354/1/6450408002. pdf> 2012.

11. Kusuma, B. F., Saleh, I., Selviana. Faktor Risiko Kejadian yang Berhubungan dengan Kejadian Demam Tifoid pada Anak di Wilayah Kerja Puskesmas Sui Kakap dan Puseksamas Sui Durian. JUMANTIK (Jurnal Mahasiswa dan Penelitian Ilmiah). 2015. p:41-53

12. Ruztam, M, Z, AHubungan Karakteristik Penderita dengan Kejadian Demam Tifoid pada Pasien Rawat Inap di RSUD Salewangan Maros. Jurnal Ilmiah Kesehatan STRADA. .2012. p:58-63

13. Dinkes Prov Jatim. Profil Kesehatan Provinsi Jawa Timur Tahun 2016. Surabaya: Dinas Kesehatan Provinsi Jawa Timur. 2017

14. Lailiyah, S.H., Athiroh, N., Santoso, H. Identifikasi Perilaku Pasien Pasca Penderita Tifoid tahun 2016 di Kelurahan Lowokmaru Kota Malang.FMIPA UNISMA, [e-jurnal Ilmiah BIOSAINTROPIS (BIOSCIENCETROPIC)]. 2018: 4. pp.1-7

15. Paputungan, W., Rombot, D. H. Akili, R. Hubungan Antara Perilaku Hidup Bersih dan Sehat dengan Kejadian Demam Tifoid di Wilayah Kerja Puskesmas Upai Kota Kotamobagu Tahun 2015. Pharmacon Jurnal Ilmiah Farmasi-UNSRAT, [ejournal. 2016: 5(2): pp.268-269.

16. Wulansari, Y. Faktor Kebiasaan dan Sanitasi Lingkungan Hubungannya dengan Kejadian Demam Typhoid di Wilayah Kerja Puskesmas Ngemplak Kabupaten Boyolali. Skripsi. Universitas Muhammadiyah Surakarta. Tersedia di:
<http://eprints.ums.ac.id/27257/11/02._NA

SKAH_PUBLIKASI.pdf $>2013$.

17. Ulfa, F. \& Oktia, W. Kejadian Demam Tifoid di Wilayah Kerja Puskesmas Pagiyanten. Higeia, 2018: 2(2).

18. Maghfiroh, A.E., Siwiendrayanti, A. Hubungan Cuci Tangan, Tempat Sampah, Kepemilikan SPAL, Sanitasi Makanan dengan Demam Tifoid.Jurnal Pena Medika, 2016: 6(1). pp:34-45

19. Nuruzzaman, H., Syahrul, F. Analisis Risiko Kejadian Demam Tifoid Berdasarkan Kebersihan Diri dan Kebiasaan Jajan di Rumah. Jurnal Epidemiologi FKM UA. 2016. pp:79

20. Zulkoni, A. Parasitologi. Yogyakarta: Nuha Medika. 2010.

21. Diana, M. Korelasi Antara Trombositopenia dengan Hemokonsentrasi Sebagai Faktor Predisposisi Terjadinya Syok pada Pasien Demam Berdarah Dengue Dewasa di RSUP Dr. Kariadi Semarang. Semarang. Fakultas Kedokteran UNDIP. Skripsi. 2007.

22. Rakhman, A. Faktor-faktor Risiko yang Berpengaruh terhadap Kejadian Demam Tifoid pada Orang Dewasa.Jurnal Berita Kedokteran Masyarakat. 2009. 25(4): pp.167-175

23. Andayani \& Fibriana, A.I. Kejadian Demam Tifoid di Wilayah Kerja Puskesmas Karangmalang. Higeia, 2018: 2(1). p.57 